\title{
Effects of an aerobic training and training cessation on skeletal muscle ultrastructure in domestic dogs
}

\author{
GERTH, N. ${ }^{1 *}$, RUOSS, C. ${ }^{1}$, JAKOB, K. ${ }^{2}$, DOBENECKER, B. ${ }^{1}$, REESE,.$^{3}$ and \\ STARCK, J. M. ${ }^{2}$ Munich, Schönleutnerstr.8, D- 85764 Oberschleißheim, Germany
${ }^{2}$ Biocenter, Department of Biology II, Ludwig-Maximilians University Munich, Großhadernerstr. 2, 82152 Planegg-Martinsried, Germany
${ }^{3}$ Chair of Anatomy, Histology, and Embryology, Department of Veterinary Sciences, Ludwig-Maximilians University Munich, Veterinärstr 13, 80539 München
*E-mail: gerth@tiph.vetmed.uni-muenchen.de \\ ${ }^{1}$ Chair of Animal Nutrition and Dietetics, Department of Veterinary Sciences, Ludwig-Maximilians University
}

\begin{abstract}
Introduction: Microbiopsies of the M.adductor magnus, which is an important locomotor muscle were taken to study the effects of six weeks of moderate aerobic treadmill training and their reversibility after a training pause of nine weeks in a group of seven Foxhound-Boxer-Ingelheim Labrador crossbreds. Materials and Methods: To study changes of myofibre morphometry standard morphometric methods were applied using light and transmission electron micrographs. Results: The capillary density was higher in trained condition than in untrained condition and after the end of training. In contrast, the capillaries per fiber as well as the capillary-to-fiber ratio, the distance between neighboring capillaries and the capillary supply area showed no significant change. Smaller myofibre diameters were found in muscles of dogs in trained condition when compared to the untrained condition but not when compared to myofibres nine weeks after the end of training. Training led to increases in the volume fraction of mitochondria within myofibres and an increase of the surface density of cristae within the mitochondria. The ratio of the surface density to the volume fraction of the mitochondria increased in response to training. Except for the decrease in myofibre diameter, all of the reported changes were reversible and measurements nine weeks after cessation of training did not differ from measurements before training started. Conclusion: The results of this study emphasize the ability of dogs to rapidly and flexibly adjust locomotor muscles to changing exercise regimes by up-and down regulation of the number and inner structure of the mitochondria while the capillary network remains stable.
\end{abstract}

Keywords: muscle morphology, dog physiology, training, mitochondria.

\section{Introduction}

Cursorial hunting mammals like canids have proportionally larger skeletal muscles, higher proportions of mitochondria and capillaries within their muscles, and higher oxidative capacities of their muscle fibers than less athletic species (WEIBEL, BACIGALUPE, SCHMITT et al., 2004).

Endurance training has been shown to lead to mitochondrial biogenesis (ZAMORA, TESSIER, MARCONNET et al., 1995; HOOD, IRRCHER, LJUBICIC et al., 2006; TARNOPOLSKY, RENNIE, ROBERTSHAW et al., 2007; HOYT, 2009). The relationship between maximum aerobic capacity and the amount of mitochondria within skeletal muscle tissue has long been established (for review see HOPPELER and FLÜCK, 2002; FLÜCK, 2006). Inconsistent results have been found regarding adaptations of muscular capillarisation to training: some human (INGJER, 1979; ZUMSTEIN, MATHIEU, HOWALD et al., 1983) and animal (study animal: rat; POOLE and MATHIEU-COSTELLO, 1996) studies found increased capillarisation after training, other animal studies revealed no changes (study animal: European woodmouse; HOPPELER, LINDSTEDT, UHLMANN et al., 1984). To compare the results of different studies is complicated due to differences in intensity and type of training scheme leading to different effects on muscles. For example in previously untrained humans, 6 weeks of endurance training led to $40 \%$ higher mitochondrial volume density, the capillary density increased by $29 \%$, and the capillary-to-fiber ratio rose by $26 \%$ but no changes were measured in myofibre diameters (HOPPELER, HOWALD, CONLEY et al., 1985). In contrast, 6 weeks of heavy-resistance training led to a $9.6 \%$ decrease of mitochondrial volume density and an $20 \%$ increase in myofibrillar volume (LÜTHI, HOWALD, CLAASSEN et al., 1986) in human volunteers. Often, the exercise scheme applied in a study is a mixture of endurance and resistance training, leading to specific adaptations of skeletal muscles. In dogs, for example, working Inuit Sled Dogs perform a combination of endurance exercise and resistance training when pulling a sled typically for 8-10 hours per day, leading to increases in fiber diameter with stable capillary network when compared to resting condition (GERTH, SUM, JACKSON et al., 2009).

Due to the plasticity of muscle tissue, the morphological characteristics of the trained muscles may change with the 
discontinuation of the training stimulus. For example, in human endurance athletes cessation of training of only 2-3 weeks led to decreases in capillary density in a study by Houston, Bentzen and Larsen (1979). In contrast, Coyle, Martin III, Sinacore et al. (1984) found no changes in capillarisation in endurance athletes after 84 days without training. Other authors (MUJIKA and PADILLA, 2001) point out that muscle fiber distribution remains unchanged during the initial weeks of inactivity, but, with prolonged inactivity a decrease in slow-twitch fibers has been found in endurance trained athletes while oxidative fiber distribution increased in resistance trained athletes.

The degree of adaptation to a given training regime also differs between different fiber types within the skeletal muscles. Because especially oxidative fibers are recruited during low intensity-endurance activities (WILMORE, COSTILL and KENNEY, 2008), they benefit most from endurance training (ABERNETHY, THAYER and TAYLOR, 1990). Skeletal muscles of dogs consist of only slow-twitch oxidative and fast-twitch oxidative fibers (BETIK, BAKER, KRAUSE et al., 2008). Therefore, dogs are excellent model organism for studying muscle adaptations to aerobic training. The measurement of capillary density and capillary-to-fiber-ratio is an important determinant of blood supply to the working muscle. Depending on the pre-training activity level of the animal, training might induce increases in capillarisation. To elucidate explicitly the effects of the training scheme and exclude factors such as different ground structures and grades at the exercise track, a homogenous group of dogs was trained indoors at constant temperatures on a treadmill at zero incline. A clear defined standardised and repeatable moderate aerobic training scheme was applied to explore structural changes within a locomotor muscle, the $M$. adductor magnus. Because an aerobic endurance training program was applied, no muscle hypertrophy but an increase in muscle mitochondria was expected. The cristae within mitochondria are the place where oxidative phosphorylation occurs; therefore changes within the mitochondrial compartment were expected. Possible changes include an increase in cristae surface density or a conformation change within the mitochondrial compartment.

Aim of the study was to test for changes of the ultrastructure of the locomotor muscle $\mathrm{M}$. adductor magnus in a homogenous group of kennel dogs after a moderate standardized aerobic treadmill training scheme and to assess the reversibility of such training effects.

\section{Animals, Materials and Methods}

\subsection{Dogs and training}

A group of seven intact female Foxhound-Boxer-Ingelheim Labrador crossbreds (4-6 years old, $29.0 \pm 2.9 \mathrm{~kg}$ body weight, range: 25.8 to $34.8 \mathrm{~kg}$ ) where used in this study. The dogs spent the day in groups of 4-5 dogs roaming freely in outdoor kennels $\left(30-55 \mathrm{~m}^{2}\right)$ and were housed individually or paired in indoor kennels $\left(9 \mathrm{~m}^{2}\right)$ between $3 \mathrm{pm}$ and $8 \mathrm{am}$ on week days and between $1 \mathrm{pm}$ and 9 am on weekends.

The dogs were accustomed to special handling procedures during a period of 10 weeks, before the actual training started. Training was conducted indoors at constant temperatures $\left(20.8 \pm 1.0{ }^{\circ} \mathrm{C}\right)$ on a custom made treadmill (WT-Metall, Bamberg, Germany) three days per week for 30-40 min per session for six weeks. To prevent overheating of the dogs during the training, a fan (Trotec, TTW 25000 S, Heinsberg, Germany) was positioned in front of the treadmill and wind speed was matched to running speed using an anemometer (Windmaster 2, Kaindl electronic, Rohrbach, Germany). Training intensity increased throughout the training period from $40 \mathrm{~min}$ trotting at $5 \mathrm{~km} / \mathrm{h}$ in the first week to $30 \mathrm{~min}$ trotting at $10 \mathrm{~km} / \mathrm{h}$ in the sixth week. Also, intensive training bouts were implemented in the training protocol starting in the fourth week including a high intensity interval training in the last training week (for details see Table 1 ). After the six weeks of training, the dogs resumed their former life style without training for another nine weeks.

\subsection{Biopsy sampling and preparation of histological material}

Microbiopsies of $\mathrm{M}$. adductor magnus were taken using a 14 gauge spring-loaded side-cutting needle (Temno; Allegiance Healthcare, McGaw Park, IL) under local anesthesia. Biopsies taken from untrained dogs were labeled "untrained I", from trained dogs were labeled as "trained", and those taken from dogs nine weeks after the end of training were labeled "untrained II". After preservation in a solution of $2.5 \%$ glutardialdehyde in $0.1 \mathrm{~mol} \mathrm{l}^{-1}$ phosphate buffer at $\mathrm{pH} 7.4$, the biopsies were post-fixed in $1 \%$ osmium tetroxide, dehydrated in a series of ethanol and pure acetone, and embedded in Epon epoxy resin

Table 1. Duration and velocities of each training bout of the six-week training period.

\begin{tabular}{cccc}
\hline Week & First training bout & Second training bout & Third training bout \\
\hline 1 & aerobic run, $40 \mathrm{~min}$ at $5 \mathrm{~km} / \mathrm{h}$ & aerobic run, $40 \mathrm{~min}$ at $5 \mathrm{~km} / \mathrm{h}$ & aerobic run, $40 \mathrm{~min}$ at $5 \mathrm{~km} / \mathrm{h}$ \\
\hline 2 & $\begin{array}{c}\text { aerobic run, } 40 \mathrm{~min}, 20 \mathrm{~min} \text { at } \\
5 \mathrm{~km} / \mathrm{h} \text { and } 20 \mathrm{~min} \text { at } 6 \mathrm{~km} / \mathrm{h}\end{array}$ & aerobic run, $40 \mathrm{~min}$ at $6 \mathrm{~km} / \mathrm{h}$ & aerobic run, $40 \mathrm{~min}$ at $6 \mathrm{~km} / \mathrm{h}$ \\
\hline 3 & aerobic run, $40 \mathrm{~min}$ at $6 \mathrm{~km} / \mathrm{h}$ & aerobic run, $40 \mathrm{~min}$ at $6 \mathrm{~km} / \mathrm{h}$ & aerobic run, $40 \mathrm{~min}$ at $6 \mathrm{~km} / \mathrm{h}$ \\
\hline 4 & aerobic run, $30 \mathrm{~min}$ at $7 \mathrm{~km} / \mathrm{h}$ & $\begin{array}{c}\text { pyramid training, } 3,2,1,1,2,3 \mathrm{~min} \\
\text { alternating at } 5 \text { and } 10 \mathrm{~km} / \mathrm{h}\end{array}$ & aerobic run, $30 \mathrm{~min}$ at $7 \mathrm{~km} / \mathrm{h}$ \\
\hline 5 & $\begin{array}{c}\text { pyramid training, } 3,2,1,1,2,3 \mathrm{~min} \\
\text { alternating at } 5 \mathrm{and} 12 \mathrm{~km} / \mathrm{h}\end{array}$ & $\begin{array}{c}\text { aerobic run, } 30 \mathrm{~min} \text { at } 8 \mathrm{~km} / \mathrm{h} \\
\text { pyramid training, } 3,2,1,1,2,3 \mathrm{~min} \\
\text { alternating at } 5 \text { and } 13 \mathrm{~km} / \mathrm{h}\end{array}$ \\
\hline 6 & aerobic run, $30 \mathrm{~min}$ at $9 \mathrm{~km} / \mathrm{h}$ & $\begin{array}{c}\text { High intensity interval-training, } 3 \mathrm{xl} \\
\text { min at } 17.5 \mathrm{~km} / \mathrm{h}, \text { alternating with } \\
3 \times 5 \mathrm{~min} \text { at } 5 \mathrm{~km} / \mathrm{h}\end{array}$ & aerobic run, $30 \mathrm{~min}$ at $10 \mathrm{~km} / \mathrm{h}$ \\
\hline
\end{tabular}


following standard protocols. Semithin sections $(500 \mathrm{~nm})$ were stained with Rüdeberg solution. Ultrathin sections $(60 \mathrm{~nm})$ were counterstained with uranlyl acetate and lead citrate.

\subsection{Histological morphometry and stereological measurements}

Histological images of the muscle samples were taken with a digital camera (Olympus DP20, Olympus, Hamburg, Germany) attached to a light microscope (Olympus BX51, Olympus, Hamburg, Germany) using the software Cell D (Olympus, Hamburg, Germany). SigmaScan Pro 4 (SYSTAT Software Inc.) was used for morphometry measurements of semithin sections through muscles in transversal alignment to the fibers. In each cross section, 20-25 fibers were investigated with 2-3 slides per dog. The methods for measurements were applied as described by Gerth, Sum, Jackson et al. (2009): 1) myofiber diameter $(\mu \mathrm{m}$, the smallest diameter of each myofibre), 2) the number of myofibres per $\mathrm{mm}^{2}$ (myofibre density, by counting the myofibres within a defined area), 3 ) the number of capillaries per $\mathrm{mm}^{2}$ (capillary density, by counting the number of capillaries within a defined area), 4) the distance between neighboring capillaries ( $\mu \mathrm{m}$, by measuring distances between any capillaries that were direct neighbors), 5 ) the capillary-to-fiber ratio (by dividing the number of capillaries per $\mathrm{mm}^{2}$ by the number of fibers per $\mathrm{mm}^{2}$ ), and 6) counted the number of capillaries associated with each myofibre. From the distance between neighboring capillaries the area $\left(\mu \mathrm{m}^{2}\right)$ supplied by each capillary was calculated using the equation $\mathrm{A}=\mathrm{r}^{2} \pi$ with $\mathrm{A}=$ area supplied by each capillary and $\mathrm{r}=0.5$ * distance between neighboring capillaries.

A transmission electron microscope (Morgagni 268, FEI, Hillsboro, Oregon USA) equipped with a digital camera (Mega View III, software iTEM 5.0; Build 1200, Olympus Soft Imaging Solutions, Hamburg, Germany) was used to obtain micrographs of muscle samples cut in random orientation. These micrographs were used for stereological assessment of the volume fraction of mitochondria within myofibrils by point counting at a magnification of $\times 5600$, as well as surface density of cristae within the mitochondria at a magnification of $\times 36000$ as outlined by Schwerzmann and Hoppeler (1985). For estimation of the volume fraction of mitochondria at least 200 pointing events have to fall on mitochondria. At each subunit of a grid that was laid over the micrographs randomly, the tissue type was assessed at a defined point (here the edge of the left side at the bottom of the unit) and counted to obtain the relative number of hits of each tissue type within the image. Point counting was done using
Fiji (SCHINDELIN, ARGANDA-CARRERAS, FRISE et al., 2012). At each magnification, 20 micrographs were assessed per dog. Furthermore, the ratio of surface density of cristae to volume fraction of mitochondria was calculated. The following equation was used to calculate the volume fractions and surface densities, respectively in a reference volume with $\Sigma \mathrm{P}$ (ref) as sum of all counting events in the reference area (myofibres and mitochondria, respectively) and $\Sigma \mathrm{P}(\mathrm{x})$ as the sum of counting events of the component of interest (mitochondria and cristae, respectively):

$\mathrm{V}(\mathrm{x})=\sum \mathrm{P}(\mathrm{x}) / \sum \mathrm{P}($ ref $)$

To obtain the ratio of surface density to volume fraction of the mitochondria, $\Sigma \mathrm{P}$ (ref) was defined as sum of all counting events that covered parts of cristae and matrix of mitochondria and $\Sigma \mathrm{P}(\mathrm{x})$ was defined as sum of all counts that fell on outer membrane of mitochondria. Tissue-free space within the micrograph was always excluded from the counting.

\subsection{Statistical analysis}

Morphometric parameters and stereological counts were analyzed using Friedman Repeated Measures Analysis of Variance on Ranks (SigmaStat 3.5, SYSTAT Software INC.) with training condition as between-subjects factor. Pairwise comparisons between the three training conditions were performed using a post-hoc analysis (Holm-Sidak Test), and the significance level was set to $\mathrm{p}<0.05$.

All procedures and protocols were conducted in accordance with the guidelines of the Protection of Animals Act and the study was approved by the representative of the Veterinary Faculty for animal welfare as well as the Government of Upper Bavaria (reference number 55.2.-1-54-2531-67-10).

\section{Results}

All dogs were healthy throughout the study and maintained a constant body mass.

\subsection{Adaptations of the myofibres and capillary network}

Micrographs of muscle fibers of dogs showed normal conformation in the three training conditions with capillaries arranged around fibers (Figure 1). No differences in size or arrangement of fibers were visible between the three conditions. The morphometric analysis of the light microscopy images showed significant differences $(\mathrm{DF}=2, \mathrm{~F}=4.85, \mathrm{p}=0.034)$ of myofibre diameter between the training conditions. Myofibre
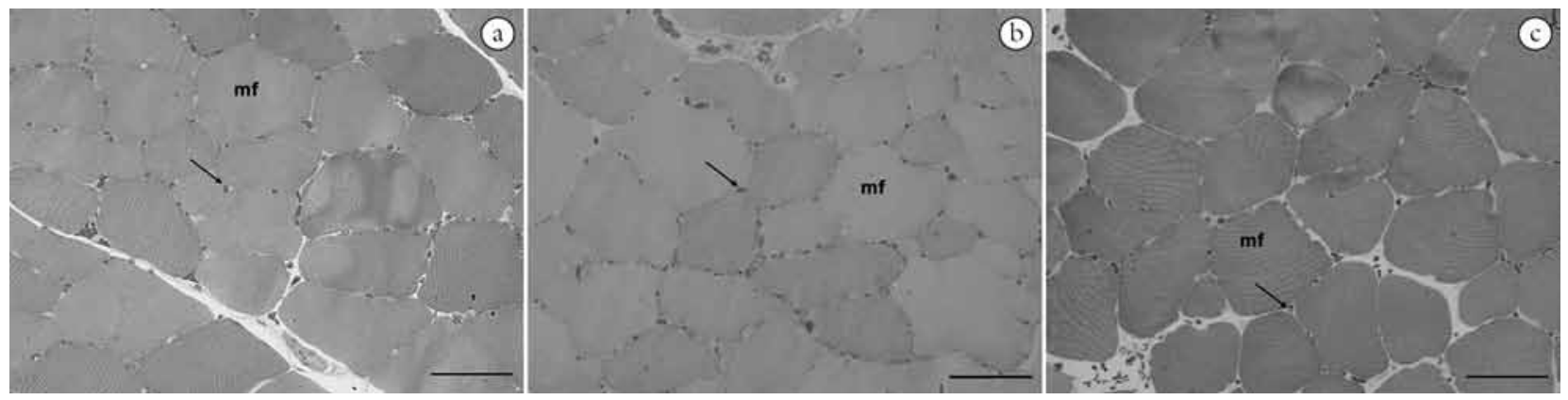

Figure 1. Light microscopy images of the myofibers ( $\mathrm{mf}$ ) within M.adductor magnus of dogs in (a) untrained, (b) trained condition, and (c) 9 weeks after training stop. Arrows point to capillaries surrounding the fibers. Scale bar represents $50 \mu \mathrm{m}$. 
diameter was smaller (Diff of Means=5.48, $\mathrm{t}=3.01, \mathrm{p}=0.013$ ) in muscle of trained dogs in comparison to the untrained I condition, but no significant differences were found between trained and untrained II. The myofibre density differed significantly $(\mathrm{DF}=2, \mathrm{~F}=5.20, \mathrm{p}=0.028)$ between conditions, density was significantly smaller (Diff of Means=125.60, $\mathrm{t}=3.22, \mathrm{p}=0.009)$ in untrained I condition when compared to trained condition but again, no differences were found between trained and untrained II condition. The capillary density differed significantly $(\mathrm{DF}=2, \mathrm{~F}=6.26, \mathrm{p}=0.017)$ : it was higher in trained condition than in untrained I (Diff of Means $=223.54, t=3.06, p=0.012)$ and untrained II condition (Diff of Means=243.38, t=3.16, p=0.010). In contrast, the capillaries per fiber as well as the capillary-to-fiber ratio, the distance between neighboring capillaries, and the capillary supply area revealed no significant change. The values of the morphometric measurements are given in Table 2 .

\subsection{Adaptations of the mitochondrial compartment}

Images of single myofibers showed normal sarcomeres in all training conditions (Figure 2). In the trained condition (Figure $2 \mathrm{~b}$ ) more mitochondria were found close by capillaries compared to untrained condition (Figure 2a, c). No differences between conditions were visible of the amount of mitochondria that are situated between myofibrils. Mitochondria were fixed in the condensed state so that the double-leaflet structure of the cristae is visible in images of all training conditions (Figure 3a-c). Next to the mitochondria numerous glycogen granules were visible as black dots. No differences in size or conformation were discernable when comparing mitochondria of the three training condition.

Using stereological counting, we measured significant differences $(\mathrm{DF}=2, \mathrm{~F}=4.56, \mathrm{p}=0.034$, Table 3 ) in the volume fraction of mitochondria with a $27.9 \%$ higher value (Diff of Means $=0.05, \mathrm{t}=2.81, \mathrm{p}=0.016)$ in trained vs. untrained $\mathrm{I}$

Table 2. Morphometry of M. adductor magnus of FBI-dogs in different training conditions: before training (untrained $\mathrm{I}, \mathrm{n}=7$ ), in trained condition (trained, $n=6$ ), and 9 weeks after the end of training (untrained II, $n=6$ ); values are mean \pm SD.

\begin{tabular}{lrrrr}
\hline & untrained I & \multicolumn{1}{c}{ trained } & untrained II \\
\hline Myofiber lesser diameter $(\mu \mathrm{m})$ & $43.54 \pm 3.71^{\mathrm{a}}$ & $38.84 \pm 4.09^{\mathrm{b}}$ & $39.85 \pm 5.14^{\mathrm{b}}$ \\
Myofiber density $\left(\right.$ per $\left.\mathrm{mm}^{2}\right)$ & $328.46 \pm 61.65^{\mathrm{a}}$ & $440.58 \pm 130.02^{\mathrm{b}}$ & $396.43 \pm 113.23^{\mathrm{b}}$ \\
Number of capillaries surrounding each myofiber & $7.13 \pm 1.11$ & $6.86 \pm 1.29$ & $6.67 \pm 1.58$ \\
Capillary density $\left(\right.$ per $\left.\mathrm{mm}^{2}\right)$ & $1295.89 \pm 92.35^{\mathrm{a}}$ & $1491.17 \pm 150.20^{\mathrm{b}}$ & $1292.55 \pm 151.20^{\mathrm{a}}$ \\
Capillary-to-fiber ratio & $4.02 \pm 0.67$ & $3.58 \pm 0.86$ & $3.45 \pm 1.07$ \\
Distance between neighboring capillaries $(\mu \mathrm{m})$ & $45.04 \pm 1.79$ & $41.68 \pm 5.66$ & $40.83 \pm 3.90$ \\
Area supplied by each capillary $\left(\mu \mathrm{m}^{2}\right)$ & $1595.55 \pm 128.46$ & $1385.39 \pm 391.89$ & $1318.96 \pm 242.23$
\end{tabular}

Significant differences are indicated by different letters behind the values.
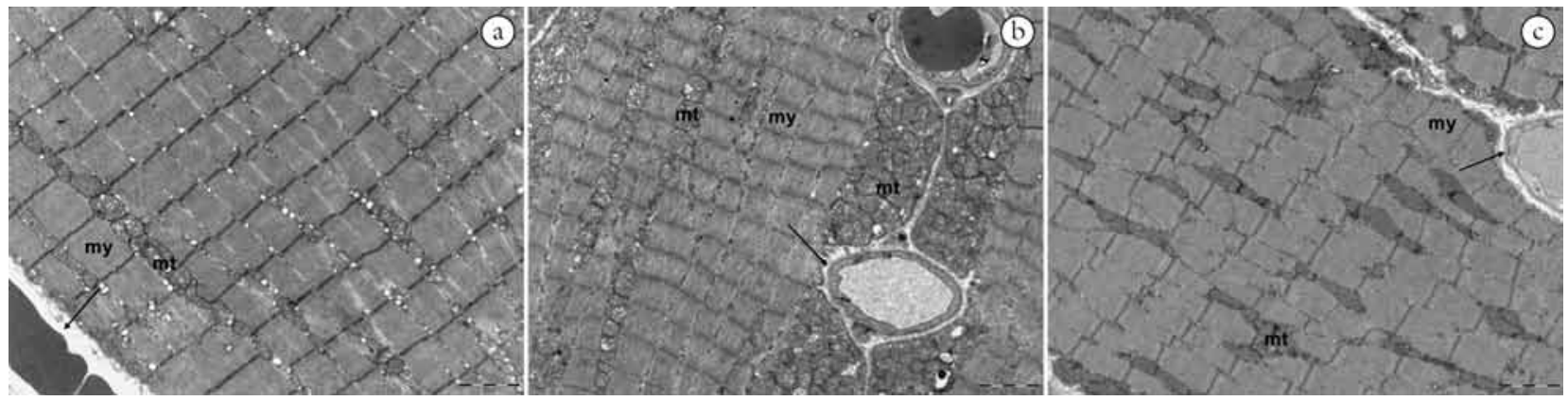

Figure 2. Transmission electron microscopy images of the myofibrils (my) and mitochondria (mt) within M.adductor magnus of dogs in (a) untrained, (b) trained condition, and (c) 9 weeks after training stop. Arrows point to capillaries between myofibers. Scale bar represents $2 \mu \mathrm{m}$.
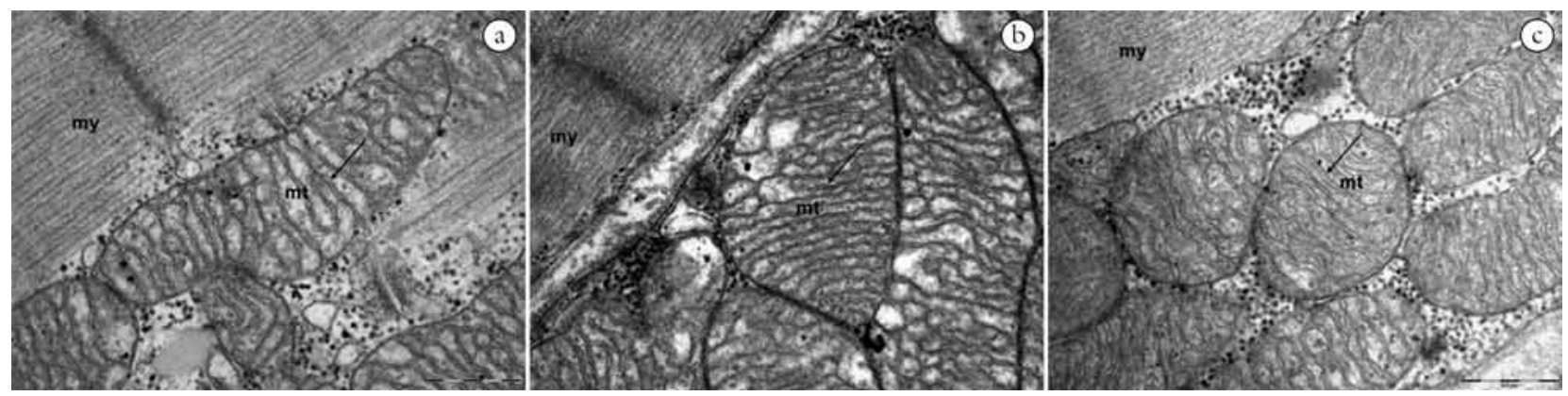

Figure 3. Transmission electron microscopy images of the mitochondria (mt) between myofibrils (my) within M.adductor magnus of dogs in (a) untrained, (b) trained condition, and (c) 9 weeks after training stop. Arrows point to cristae within the mitochondria. Scale bar represents $0.5 \mu \mathrm{m}$. 
Table 3. Volume fractions and surface densities of different ultrastractural parameters of FBI-dogs calculated from stereology counts from TEM-images of M.adductor magnus in different training conditions: before training (untrained $\mathrm{I}, \mathrm{n}=7$ ), in trained condition (trained, $\mathrm{n}=6$ ), and nine weeks after the end of training (untrained II, $\mathrm{n}=6$ ); values are mean \pm SD.

\begin{tabular}{llcc}
\hline \multicolumn{1}{c}{ Volume fractions } & Untrained I & Trained & Untrained II \\
\hline Mitochondria within myofibres & $0.18 \pm 0.02^{\mathrm{a}}$ & $0.22 \pm 0.03^{\mathrm{b}}$ & $0.18 \pm 0.03^{\mathrm{a}}$ \\
Cristae within mitochondria & $0.94 \pm 0.03^{\mathrm{a}}$ & $1.05 \pm 0.08^{\mathrm{b}}$ & $0.92 \pm 0.06^{\mathrm{a}}$ \\
Surface density of cristae/ volume fraction of mitochondria & $0.36 \pm 0.02^{\mathrm{a}}$ & $0.44 \pm 0.03^{\mathrm{b}}$ & $0.36 \pm 0.02^{\mathrm{a}}$ \\
\hline
\end{tabular}

Significant differences are indicated by different letters behind the values.

condition. Compared to the trained condition, the volume fraction of mitochondria was $22.5 \%$ lower in untrained II condition (Diff of Means=0.04, t=2.37, $\mathrm{p}=0.04$ ). Significant differences $(\mathrm{DF}=2, \mathrm{~F}=16.74, \mathrm{p}<0.001)$ were also found in the surface density of cristae within the mitochondria (Figure 3 ) with a $22.8 \%$ higher density (Diff of Means=0.08, $\mathrm{t}=5.31$, $\mathrm{p}<0.001)$ in trained compared to untrained I condition. In untrained II condition, the surface density of cristae within the mitochondria was $21.4 \%$ lower $($ Diff of Means $=0.08, \mathrm{t}=4.80$, $\mathrm{p}<0.001)$ than the values of dogs in trained condition. The ratio of the surface density to volume fraction of the mitochondria changed significantly $(\mathrm{DF}=2, \mathrm{~F}=6.89, \mathrm{p}=0.013)$ between training conditions with an $11.8 \%$ higher value (Diff of Means $=0.118$, $\mathrm{t}=3.24, \mathrm{p}=0.008)$ in trained condition compared to untrained I condition and a $13.3 \%$ smaller value (Diff of Means $=0.126$, $\mathrm{t}=3.28, \mathrm{p}=0.009)$ in untrained II versus trained condition. Values of the untrained I condition did not differ from the untrained II condition for all measurements taken.

\section{Conclusions}

The aim of this study was to explore structural changes of $\mathrm{M}$. adductor magnus in response to a moderate aerobic training regime and the reversibility of effects after a training pause of nine weeks. No muscle hypertrophy was expected with the applied training scheme, but an increase in muscle mitochondria as well as an increase in cristae surface density was anticipated because the cristae within mitochondria are the place where oxidative phosphorylation occurs.

\subsection{Adaptations of the myofibres and capillary network}

Endurance training led to a decrease in myofibre diameter in the dogs lasting until nine weeks after the end of training. As mentioned before, skeletal muscles of dogs consist of fibers with uniformly high aerobic potential and low glycolytic capacity (ARMSTRONG, SAUBERT, SEEHERMAN et al., 1982; SNOW, BILLETER, MASCARELLO et al., 1982; KUZON JUNIOR, ROSENBLATT, PYNN et al., 1989). According to Armstrong, Saubert, Seeherman et al. (1982) the M. adductor magnus consists of 28 to $46 \%$ of oxidative fibers which are susceptible to aerobic training (ABERNETHY, THAYER and TAYLOR, 1990; WILMORE, COSTILL and KENNEY, 2008). The values for fiber diameter measured here (38.8-43.5 $\mu \mathrm{m})$ were at or below the lower end of values reported for dogs of 40.5-53.7 $\mu \mathrm{m}$ by Kuzon Junior, Rosenblatt, Pynn et al. (1989) and 50-64 $\mu \mathrm{m}$ reported by Z'berg and Augsburger (2002). Breed specific variations may account for the difference in fiber size, for example were type II (glycolytic) fibers of the M. gracilis of hound-type dogs $12.7 \mu \mathrm{m}$ thicker than the same fibers in Beagles with $41.0 \mu \mathrm{m}$ (KUZON JUNIOR,
ROSENBLATT, PYNN et al., 1989). The origin of the specific fibers could also account for the differences, for example type I (oxidative) fibers differed by $9.5 \mu \mathrm{m}$ between the $\mathrm{M}$. gracilis $(56.3 \mu \mathrm{m})$ and the caudal part of $\mathrm{M}$. sartorius $(46.8 \mu \mathrm{m})$ in hound-type dogs in the aforementioned study. In this study, no information is available about the type of the fibers that were analyzed. Only the change of mean diameter of all investigated fibers due to training level is reported here. No information from the literature could be found as to effects of moderate endurance training on fiber diameter. Therefore, it can only be speculated why the muscle fiber diameter decreased after the applied treadmill training. A possible explanation for the thicker muscle fibers in the untrained condition is that the dogs were more stressed at the first sampling occasion and therefore their muscles were tensed at the moment the biopsies were taken. This might have led to a larger diameter of tensed muscle fibers. At the second and third sampling day they might have been more accustomed to the handling and sound during the procedure. A systematic measurement error is unlikely because only cross sections were included in this measurement and only the smallest diameter was recorded, so no overestimation due to oblique sections through fibers occurred.

A stable capillary network of the locomotor muscles was found throughout the training and non-training periods as seen in the constant capillary-to-fiber ratio, number of capillaries surrounding a fiber, and distance between neighboring capillaries which led to unchanged areas supplied by each capillary. Only capillary density was significantly higher in trained condition when compared to both untrained conditions. Of all measurements conducted here, this is the most sensitive method in respect to measurement error. If, for example, some sections in a specific training condition were cut in a slightly oblique angle to the fibers, then the area occupied by myofibre tissue would be proportionally larger than in actual cross sections. The capillary density is derived from counts of sections through capillaries per area and the density would be underestimated in slightly oblique section because of the larger portion of myofibre tissue then in cross sections. With the reduction in fiber diameter from untrained to trained condition the fiber density rose, and so did the capillary density. If the capillary network did not change, than the capillary density inevitably increased with the reduction of myofibre diameter. This leads to the conclusion that the architecture of the capillary network was sufficient to ensure oxygen transport to the muscles throughout the entire study. Similar results have been reported when comparing Inuit Sled Dogs during summer resting condition with the same dogs in winter working condition (GERTH, SUM, JACKSON et al., 2009). In humans, endurance training has been linked to increased capillarisation (KIENS, ESSEN-GUSTAVSSON, 
CHRISTENSEN et al., 1993), whereas Zumstein, Mathieu, Howald et al. (1983) found no differences in capillary density when comparing untrained men and women with well-trained orienteers. Hoppeler, Lindstedt, Uhlmann et al. (1984) found that capillary densities were neither affected by training nor by inactivation through light exposure during night time in another animal, the European woodmouse. The unchanged capillary network found in the study at hand is well in line with the aforementioned studies, especially because of the moderate nature and relatively short duration of the training applied here.

Conflicting results have been found in human studies regarding changes in capillarisation after the cessation of training. While Coyle, Martin III, Sinacore et al. (1984) found no changes in capillarisation of endurance trained humans after 84 days without training, Houston, Bentzen and Larsen (1979) reported a decrease in capillary density already within 2-3 weeks of inactivity in endurance athletes. Again, given the short duration of the mild training applied in the study at hand, it is not surprising that no changes of capillarisation were found throughout the study.

The values for capillary density and number of capillaries surrounding a fiber measured here seem very high compared to other studies: Nguyen, Guigand, Goubault-Leroux et al. (2005) found densities of 316-401 capillaries per $\mathrm{mm}^{2}$ in young dogs (4-10 months old), Kuzon Junior, Rosenblatt, Pynn et al. (1989) report values between 412-886 capillaries per $\mathrm{mm}^{2}$ and 4.4-7.2 capillaries surrounding a fiber in young adult dogs (15-24 months old). Gerth, Sum, Jackson et al. (2009) previously found values ranging from 624 to 1041 capillaries per $\mathrm{mm}^{2}$ and 4.5-6.6 capillaries surrounding a fiber in adult dogs (2-4 years of age). Age could be the explanation for these differences because the dogs in this study were considerably older (4-6 years old). Similar observations have been made in rats of different age (MATHIEU-COSTELLO, JU, TREJO-MORALES et al., 2005). Also, the dogs used in the study at hand already had a good fitness level at the beginning due to the daily free group activity in the outdoor runs what might explain the relatively high capillarisation values reported here.

\subsection{Adaptations of the mitochondrial compartment}

The mitochondrial compartment flexibly adapted to the changing exercise regimes by up- and down-regulation (Table 3 ). The reported changes of mitochondria and cristae within mitochondria of the muscles were reversible by 9 weeks without training. Numerous studies reported an increase in mitochondrial volume due to endurance training, for example in rats (POOLE and MATHIEU-COSTELLO, 1996), mice (HOPPELER, LINDSTEDT, UHLMANN et al., 1984), horses (TYLER, GOLLAND, EVANS et al., 1998), and in humans (HOPPELER, HOWALD, CONLEY et al., 1985; ZAMORA, TESSIER, MARCONNET et al., 1995; TARNOPOLSKY, RENNIE, ROBERTSHAW et al., 2007). The rapid remission of mitochondrial adaptations to endurance training with the cessation of training has been shown at least in mitochondrial enzyme levels. For example, a treadmill training for 15 weeks doubled some mitochondrial marker enzymes in rats, with the activities of these enzymes returning to baseline values between 28-35 days after training cessation (BOOTH and HOLLOSZY, 1977). In humans who had trained for 8 weeks, the increase in mitochondrial enzyme levels was reversed within 8 weeks of exercise cessation (KLAUSEN, ANDERSEN and PELLE, 1981). Holloszy and Coyle (1984) pointed out that the increase in mitochondrial volume within skeletal muscles with endurance training is mediated by the contractile activity during exercise and not by exogenous stimuli such as alterations in hormonal status because mitochondrial adaptations are limited to the muscle fibers recruited in the specific exercise. Because the $M$. adductor magnus is involved in treadmill running and the muscle consists mainly of oxidative fibers that are recruited during submaximal running as applied in this study, the almost $30 \%$ increase in volume fraction of mitochondria is not surprising. Also, the almost complete return to baseline levels after nine weeks of training cessation is in agreement with the aforementioned studies on humans and rats. Not only volume fraction of mitochondria changed with training but also the internal structure of the mitochondria in the study at hand. Surface density of the cristae within mitochondria increased by $23 \%$ with training and returned to baseline levels after nine weeks without training. So training does not just lead to the production of more mitochondria of the same kind but also alters the internal structure and presumably the physiological parameters and function of the mitochondrial network as pointed out by Gnaiger (2009). Votion, Gnaiger, Lemieux et al. (2012) highlighted the importance that qualitative changes in mitochondrial function are superimposed on a shift towards higher mitochondrial density in trained horses when compared to untrained horses. Another indicator of change in mitochondrial network architecture is the ratio of the surface density to volume fraction of the mitochondria. This ratio was similar in the two untrained conditions, but the value was almost $12 \%$ higher in the trained condition. The smallest value could be obtained in circular sections. The more oblique or longitudinal a section through a mitochondrion is, the higher the value of ratio of circumference to area. A stronger interconnection between mitochondria within the myofibres would increase the chance to hit longitudinal sections through branches of the mitochondrial network. We interpret this significant change in the trained state as a sign of a more intensively developed mitochondrial network with more linkages developed between the subsarcolemmal and intermyofibrillar mitochondria as discussed by Kirkwood, Munn and Brooks et al. (1986).

\section{Summary}

Moderate aerobic endurance training for six weeks led to an increase in mitochondrial volume fraction and in surface density of cristae within mitochondria, as well as a different ratio of the surface density to volume fraction of the mitochondria in Foxhound crossbred dogs. The muscle fiber diameter decreased in response to training but the capillary network remained unchanged. After a training pause of nine weeks the aforementioned alterations of the mitochondrial compartment had returned to base line levels. Only the myofibre diameter did not return to baseline values with cessation of training. The results of this study emphasize the ability of dogs to rapidly and flexibly adjust locomotor muscles to changing exercise regimes by up- and down-regulation of number as well as inner structure of mitochondria while the capillary network remains stable. 
Acknowledgements: We thank the staff of the animal facility of the Chair of Animal Nutrition and Dietetics, Ludwig Maximilians University, especially Dr. Julia Fritz, for taking care of the dogs. We also thank Julia Faltermeier for her help in the laboratory.

\section{References}

ABERNETHY, PJ., THAYER, R. and TAYLOR, AW. Acute and chronic responses of skeletal muscle to endurance and sprint exercise: a review. Sports Medicine, 1990, vol. 10, n. 6, p. 365-389. http:// dx.doi.org/10.2165/00007256-199010060-00004. PMid:2291032.

ARMSTRONG, RB., SAUBERT, CW., SEEHERMAN, HJ. and TAYLOR, CR. Distribution of fiber types in locomotory muscles of dogs. The American Journal of Anatomy, 1982, vol. 163, n. 1, p. 87 98. http://dx.doi.org/10.1002/aja.1001630107. PMid:6460435.

BETIK, AC., BAKER, DJ., KRAUSE, DJ., MCCONKEY, MJ. and HEPPLE, RT. Exercise training in late middle-aged male Fischer 344 $\times$ Brown Norway Fl-hybrid rats improves skeletal muscle aerobic function. Experimental Physiology, 2008, vol. 93, n. 7, p. 863-871. http://dx.doi.org/10.1113/expphysiol.2008.042069. PMid:18356556.

BOOTH, FW. and HOLLOSZY, JO. Cytochrome c turnover in rat skeletal muscles. The Journal of Biological Chemistry, 1977, vol. 252, n. 2, p. 416-419. PMid:188815.

COYLE, EF., MARTIN III, WH., SINACORE, DR., JOYNER, MJ., HAGBERG, JM. and HOLLOSZY, JO. Time course of loss of adaptations after stopping prolonged intense endurance training. Journal of Applied Physiology: Respiratory, Environmental and Exercise Physiology, 1984, vol. 57, n. 6, p. 95-99. PMid:6511559.

FLÜCK, M. Functional, structural and molecular plasticity of mammalian skeletal muscle in response to exercise stimuli. The Journal of Experimental Biology, 2006, vol. 209, n. Pt 12, p. 2239-2248. http://dx.doi.org/10.1242/jeb.02149. PMid:16731801.

GERTH, N., SUM, S., JACKSON, S. and STARCK, JM. Muscle plasticity of Inuit sled dogs in Greenland. The Journal of Experimental Biology, 2009, vol. 212, n. Pt 8, p. 1131-1139. http://dx.doi. org/10.1242/jeb.028324. PMid:19329747.

GNAIGER, E. Capacity of oxidative phosphorylation in human skeletal muscle: new perspectives of mitochondrial physiology. The International Journal of Biochemistry \& Cell Biology, 2009, vol. 41, p. 1837-1845.

HOLLOSZY, JO. and COYLE, EF. Adaptations of skeletal muscle to endurance exercise and their metabolic consequences. Journal of Applied Physiology, 1984, vol. 56, n. 4, p. 831-838. PMid:6373687.

HOOD, DA., IRRCHER, I., LJUBICIC, V. and JOSEPH, A-M. Coordination of metabolic plasticity in skeletal muscle. The Journal of Experimental Biology, 2006, vol. 209, n. Pt 12, p. 2265-2275. http://dx.doi.org/10.1242/jeb.02182. PMid:16731803.

HOPPELER, H. and FLÜCK, M. Normal mammalian skeletal muscle and its phenotypic plasticity. The Journal of Experimental Biology, 2002, vol. 205, n. Pt 15, p. 2143-2152. PMid:12110647.

HOPPELER, H., HOWALD, H., CONLEY, K., LINDSTEDT, SL., CLAASSEN, H., VOCK, P. and WEIBEL, ER. Endurance training in humans: aerobic capacity and structure of skeletal muscle. Journal of Applied Physiology, 1985, vol. 59, n. 2, p. 320-327.

HOPPELER, H., LINDSTEDT, SL., UHLMANN, E., NIESEL, A., CRUZ-ORIVE, LM. and WEIBEL, ER. Oxygen consumption and the composition of skeletal muscle tissue after training and inactivation in the European woodmouse (Apodemus sylvaticus). Journal of Comparative Physiology, 1984, vol. 155, n. 1, p. 51-61. http://dx.doi.org/10.1007/BF00688791.

HOUSTON, ME., BENTZEN, H. and LARSEN, H. Interrelationships between skeletal muscle adaptations and performance as studied by detraining and retraining. Acta Physiologica Scandinavica, 1979, vol. 105, n. 2, p. 163-170. http://dx.doi.org/10.1111/j.1748-1716.1979. tb06328.x. PMid:420018.

HOYT, T. Skeletal muscle benefits of endurance training: mitochondrial adaptations. American Medical Athletic Association Journal, 2009, p. 14-16.

INGJER, F. Effects of endurance training on muscle fibre ATP-ase activity, capillary supply and mitochondrial content in man. The Journal of Physiology, 1979, vol. 294, n. 1, p. 419-432. http://dx.doi. org/10.1113/jphysiol.1979.sp012938. PMid:159945.

KIENS, B., ESSEN-GUSTAVSSON, B., CHRISTENSEN, NJ. and SALTIN, B. Skeletal muscle substrate utilization during submaximal exercise in man: effect of endurance training. The Journal of Physiology, 1993, vol. 469, n. 1, p. 459-478. http://dx.doi.org/10.1113/ jphysiol.1993.sp019823. PMid:8271208.

KIRKWOOD, SP., MUNN, EA. and BROOKS, GA. Mitochondrial reticulum in limb skeletal muscle. American Journal of Physiology, 1986, vol. 251, n. 3 Pt 1, p. C395-C402. PMid:3752235.

KLAUSEN, K., ANDERSEN, LB. and PELLE, I. Adaptive changes in work capacity, skeletal muscle capillarization and enzyme levels during training and detraining. Acta Physiologica Scandinavica, 1981, vol. 113, n. 1, p. 9-16. http://dx.doi.org/10.1111/j.1748-1716.1981. tb06854.x. PMid:7315443.

KUZON JUNIOR, WM., ROSENBLATT, JD., PYNN, BR., MARCHETTI, PJ., PLYLEY, MJ. and MCKEE, NH. A comparative histochemical and morphometric study of canine skeletal muscle. Canadian Journal of Veterinary Research, 1989, vol. 53, n. 2, p. 125-132. PMid:2523755.

LÜTHI, JM., HOWALD, H., CLAASSEN, H., RÖSLER, K., VOCK, P. and HOPPELER, H. Structural changes in skeletal muscle tissue with heavy-resistance exercise. International Journal of Sports Medicine, 1986, vol. 7, n. 3, p. 123-127. http://dx.doi. org/10.1055/s-2008-1025748. PMid:2942497.

MATHIEU-COSTELLO, O., JU, Y., TREJO-MORALES, M. and CUI, L. Greater capillary-fiber interface per fiber mitochondrial volume in skeletal muscles of old rats. Journal of Applied Physiology, 2005, vol. 99, n. 1, p. 281-289. http://dx.doi.org/10.1152/ japplphysiol.00750.2004. PMid:15774695.

MUJIKA, I. and PADILLA, S. Muscular characteristics of detraining in humans. Medicine and Science in Sports and Exercise, 2001, vol. 33 , n. 8, p. 1297-1303. http://dx.doi.org/10.1097/00005768200108000-00009. PMid:11474330.

NGUYEN, F., GUIGAND, L., GOUBAULT-LEROUX, I., WYERS, M. and CHEREL, Y. Microvessel density in muscles of dogs with golden retriever muscular dystrophy. Neuromuscular Disorders, 2005, vol. 15, n. 2, p. 154-163. http://dx.doi.org/10.1016/j. nmd.2004.11.002. PMid:15694137.

POOLE, DC. and MATHIEU-COSTELLO, O. Relationship between fiber capillarization and mitochondrial volume density in control and trained rat soleus and plantaris muscles. Microcirculation (New York, N.Y.), 1996, vol. 3, n. 2, p. 175-186. http://dx.doi. org/10.3109/10739689609148286. PMid:8839439.

SCHINDELIN, J., ARGANDA-CARRERAS, I., FRISE, E., KAYNIG, V., LONGAIR, M., PIETZSCH, T., PREIBISCH, S., RUEDEN, C., SAALFELD, S., SCHMID, B., TINEVEZ, J-Y., WHITE, DJ., HARTENSTEIN, V., ELICEIRI, K., TOMANCAK, P. and CARDONA, A. Fiji: an open-source platform for biological-image analysis. Nature Methods, 2012, vol. 9, n. 7, p. 676-682. http:// dx.doi.org/10.1038/nmeth.2019. PMid:22743772.

SCHWERZMANN, K. and HOPPELER, H. Stereology: a working tool for cell biologists. Trends in Biochemical Sciences, 1985, vol. 10, n. 5, p. 184-187. http://dx.doi.org/10.1016/0968-0004(85)90183-5. 
SNOW, DH., BILLETER, R., MASCARELLO, F., CARPENE, E., ROWLERSON, A. and JENNY, E. No classical type IIB fibres in dog skeletal muscle. Histochemistry, 1982, vol. 75, n. 1, p. 53-65. http:// dx.doi.org/10.1007/BF00492533. PMid:6181029.

TARNOPOLSKY, MA., RENNIE, CD., ROBERTSHAW, HA., FEDAK-TARNOPOLSKY, SN., DEVRIES, MC. and HAMADEH, MJ. Influence of endurance exercise training and sex on intramyocellular lipid and mitochondrial ultrastructure, substrate use, and mitochondrial enzyme activity. American Journal of Physiology. Regulatory, Integrative and Comparative Physiology, 2007, vol. 292, n. 3, p. Rl271-R1278. http://dx.doi.org/10.1152/ajpregu.00472.2006. PMid:17095651.

TYLER, CM., GOLLAND, LC., EVANS, DL., HODGSON, DR. and ROSE, RJ. Skeletal muscle adaptations to prolonged training, overtraining and detraining in horses. Pflïgers Archiv, 1998, vol. 436, n. 3, p. 391-397. http://dx.doi.org/10.1007/s004240050648. PMid:9644221.

VOTION, D-M., GNAIGER, E., LEMIEUX, H., MOUITHYSMICKALAD, A. and SERTEYN, D. Physical fitness and mitochondrial respiratory capacity in horse skeletal muscle. PLoS One, 2012, vol. 7, n. 4, p. e34890. http://dx.doi.org/10.1371/journal.pone.0034890. PMid:22529950.

WEIBEL, ER., BACIGALUPE, LD., SCHMITT, B. and HOPPELER, $\mathrm{H}$. Allometric scaling of maximal metabolic rate in mammals: muscle aerobic capacity as determinant factor. Respiratory Physiology \&
Neurobiology, 2004, vol. 140, n. 2, p. 115-132. http://dx.doi. org/10.1016/j.resp.2004.01.006. PMid:15134660.

WILMORE, JH., COSTILL, DL. and KENNEY, WL. 2008. Physiology of sport and exercise science. 4th ed. Human Kinetics.

Z'BERG, C. and AUGSBURGER, HR. Differences of morphometrical parameters in hind limb muscle fibres between ovarectomized and sexually intact female dogs. Annals of Anatomy. Anatomischer Anzeiger, 2002, vol. 184, n. 2, p. 165-172. http://dx.doi.org/10.1016/ S0940-9602(02)80012-7. PMid:11936197.

ZAMORA, AJ., TESSIER, F., MARCONNET, P., MARGARITIS, I. and MARINI, JF. Mitochondria changes in human muscle after prolonged exercise, endurance training and selenium supplementation. European Journal of Applied Physiology and Occupational Physiology, 1995, vol. 71, n. 6, p. 505-511. http://dx.doi.org/10.1007/ BF00238552. PMid:8983917.

ZUMSTEIN, A., MATHIEU, O., HOWALD, H. and HOPPELER, $\mathrm{H}$. Morphometric analysis of the capillary supply in skeletal muscles of trained and untrained subjects-its limitations in muscle biopsies. Pflïgers Archiv, 1983, vol. 397, n. 4, p. 277-283. http://dx.doi. org/10.1007/BF00580261. PMid:6889095.

Received October 8, 2015 Accepted November 12, 2015 